\title{
AUDINIŲ PERFUZIJOS VERTINIMAS ŠOKO METU
}

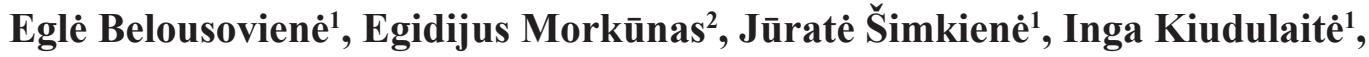 \\ Vidas Pilvinis ${ }^{1}$, Andrius Pranskūnas ${ }^{1}$ \\ ${ }^{I}$ Lietuvos sveikatos mokslu universiteto Medicinos akademijos Intensyviosios terapijos klinika, \\ ${ }^{2}$ Lietuvos sveikatos mokslu universiteto Medicinos akademijos Gastroenterologijos klinika
} kas.

Raktažodžiai: audinių perfuzija, mikrocirkuliacija, šo-

\section{Santrauka}

Audinių kraujotakos pablogèjimas yra esminis organų nepakankamumo vystymosi veiksnys šoko metu. Nustatytas reikšmingas ryšys tarp audinių perfuzijos sutrikimo laipsnio ir pacientų mirštamumo, todèl labai svarbu kuo anksčiau nustatyti pablogejjusią audinių perfuziją ir imtis terapinių veiksmų. Šio straipsnio tikslas - apžvelgti naujausią literatūrą, kurioje aprašomi neinvaziniai audiniu perfuzijos vertinimo bei gerinimo būdai. Duomenys buvo renkami PubMed duomenų bazejje, naudojant raktinius žodžius: tissue perfusion, microcirculation, shock. Atrinkti ir išanalizuoti 52 viso teksto straipsniai anglu kalba. Analizès rezultatai parodè, kad audinių perfuzijos vertinimas klinikiniais, biocheminiais bei instrumentiniais metodais leidžia anksti įtarti ir nustatyti audinių perfuzijos sutrikimus. Ankstyvas kraujotakos nepakankamumo nustatymas ir laiku vykdomos terapinès intervencijos, gerinančios audinių perfuziją, didina pacientų išgyvenamumą šoko metu.

\section{Ivadas}

Aerobiniam metabolizmui palaikyti būtinas nuolatinis ląstelių aprūpinimas deguonimi, kurị užtikrina mikrokraujagyslių kraujotaka [1]. Šoko metu vienas svarbiausių veiksnių, sukeliančių organų nepakankamumą, yra audinių hipoksija, kurios prigimtis siejama su kraujotakos pablogèjimu [2-4]. Sumažejus funkcionuojančių kapiliarų tankiui, deguonis sunkiau patenka ị ląstelę, nes turi prasiskverbti daug didesnį atstumą, negu sveiko žmogaus audiniuose. Jei bendra organo kraujotaka stambiujų kraujagyslių lygmenyje ir išsaugoma, dèl mikrokraujagyslių kraujotakos netolygumo pablogèja deguonies pasisavinimas audinių ląstelèse, atsiranda hipoksijos zonos [5]. Pastebèta, kad mikrocirkuliacijos sutrikimai šoko metu išlieka, nepaisant koreguotų sisteminès hemodinamikos parametrų, o jos sutrikimo laipsnis siejamas su didesniu organų nepakankamumo dažniu bei blogesne baigtimi [6].

Intensyviosios terapijos skyriaus pacientų ankstyvieji kraujotakos nepakankamumo gydymo tikslai yra išsaugoti kraujotaką, palaikyti reikiamą arterinị kraujospūdị bei užtikrinti deguonies transportą makrokraujagyslèmis. Tokiu būdu tikimasi pagerinti mikrocirkuliaciją bei aerobinį metabolizmą ląstelèse [1]. Dél jau minèto neatitikimo tarp kraujotakos stambiosiomis kraujagyslèmis ir mikrokraujagyslèmis, tikslinga šoko metu stebèti ne tik ịprastinius hemodinamikos parametrus, bet ir audinių perfuziją kapiliarų lygmenyje [6]. Straipsnyje aptariami klinikiniai, biocheminiai ir instrumentiniai audinių perfuzijos vertinimo būdai, bei auksiniu standartu mikrocirkuliacijai vertinti laikoma tamsaus lauko kraštinio srauto videomikroskopija.

Tyrimo tikslas - apžvelgti naujausią literatūrą, kurioje aprašomi neinvaziniai audinių perfuzijos vertinimo bei gerinimo būdai.

\section{Tyrimo medžiaga ir metodai}

Buvo išanalizuoti literatūros šaltiniai, nagrinejjantys audinių perfuzijos vertinimo metodiką bei jos gerinimo būdus, parašyti anglų kalba. Paieška atlikta tarptautinejje medicinos duomenų bazejje PubMed, naudojant raktažodžius anglų kalba: tissue perfusion, microcirculation, shock. I apžvalgą itrauktos ir išanalizuotos 52 viso teksto publikacijos, atitinkančios nagrinejjamą temą.

\section{Tyrimo rezultatai}

\section{Klinikinis periferinès perfuzijos vertinimas}

Šoko ankstyvoje fazeje, kai vyrauja kompensaciniai mechanizmai, pablogejjusi odos perfuzija bei tachikardija gali būti pirmieji matomi požymiai. Šoko metu kraujotaka nukreipiama nuo mažiau svarbių (pvz., odos, raumenų) link gyvybiškai svarbių organų (širdis, smegenys, inkstai). Paprastai ir greitai galima ịvertinti odos temperatūrą, kapiliarų prisipildymo laiką, odos margumą [1].

Kūno temperatūros gradientas. Buvo pastebèta, kad 
pacientams, kurių galūnès šaltos, per 48 val. gydymo intensyviosios terapijos skyriuose (ITS) organų nepakankamumo atvejų nustatoma daugiau, nei tiems, kurių odos temperatūra normali [7]. Audinių hipoperfuziją labiau atspindi dviejų kūno vietų temperatūrų skirtumas, nei vienos kūno dalies temperatūra. Jis gali būti matuojamas įvairiai: tarp vidinès ir periferinès temperatūrų, tarp dilbio ir piršto odos, tarp vidinès temperatūros ir aplinkos, tarp aplinkos ir didžiojo kojos piršto. Šie gradientai neturi ryšio su minutiniu širdies tūriu, tačiau yra prognostinis organų nepakankamumo ir mirštamumo veiksnys [7]. Kai audiniai gerai aprūpinami krauju, šiluma perduodama iš kūno vidaus ị periferiją. Kraujotakai prastejjant, jos perduodama mažiau. Dèl vazokonstrikcijos sumažèjus odos temperatūrai bei šilumos perdavimui ị periferiją, didèja vidinè temperatūra, todèl ryškèja vidinès bei periferinès temperatūros skirtumas. Esant stabiliai kraujotakai, jis būna $3-7{ }^{\circ} \mathrm{C}[8]$.

Jei aplinkos temperatūra mažesnè kaip $20{ }^{\circ} \mathrm{C}$, pacientui yra hipotermija ar šokas dèl vazodilatacijos, toks audinių kraujotakos vertinimo metodas nèra patikimas. Tokiu atveju tikslesnis būtų temperatūros gradiento tarp dilbio bei piršto

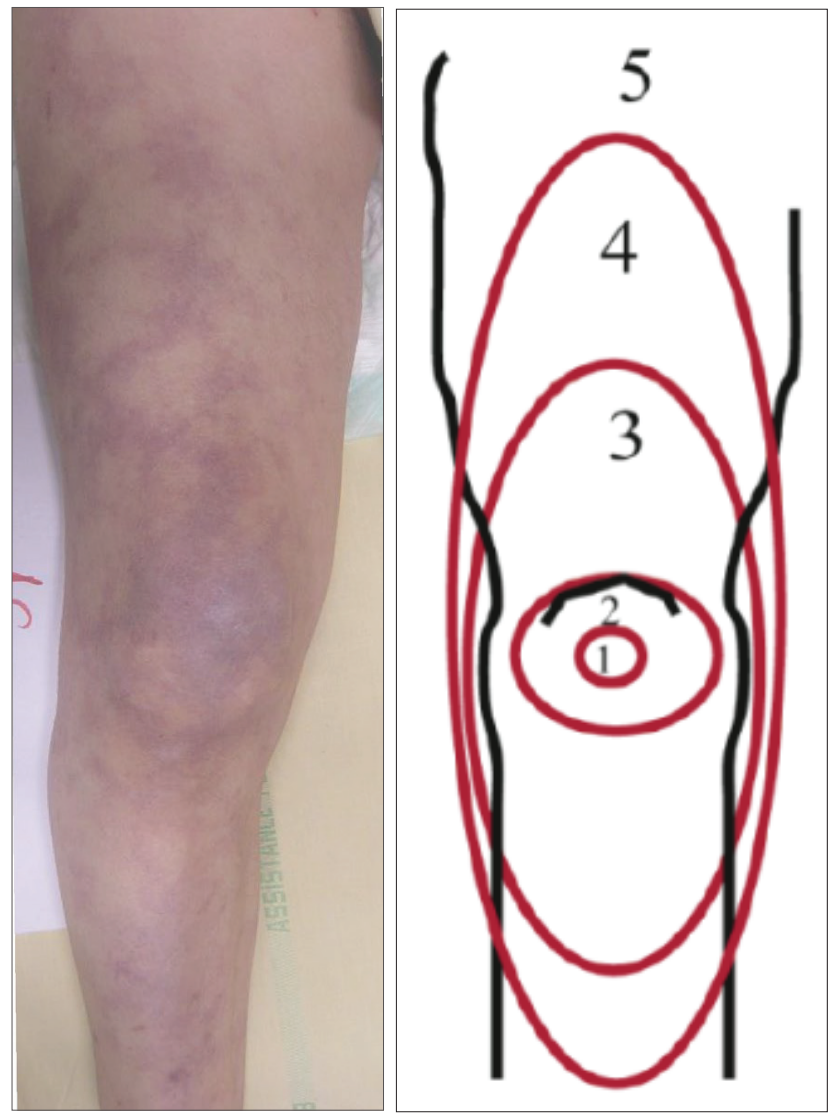

1 pav. Odos margumo laipsniai matavimas. Jo privalumas tas, kad abi vietas aplinkos temperatūra veikia panašiai. Periferinè temperatūra matuojama ant pilvinio rankos rodomojo piršto paviršiaus pritvirtinus termometrą. Dilbio temperatūros daviklis fiksuojamas ant stipinkaulinio dilbio paviršiaus, viduryje tarp alkūnès ir riešo. Normalus skirtumas lygus $0{ }^{\circ} \mathrm{C}$, o jo padidejimas iki $4{ }^{\circ} \mathrm{C}$ siejamas su didelio laipsnio vazokonstrikcija [8].

Kapiliarų prisipildymo laikas (KPL). Tai paprastas, neribojamas turimų išteklių metodas periferinei perfuzijai ivertinti. Jis gan greitai kinta taikant terapines priemones, todèl yra parankus vertinant jų efektyvumą [9].

KPL vadinamas laikas, per kurị atokesnè kapiliarų ložè (pavyzdžiui, nagas) atgauna spalvą po to, kai buvo suspausta iki blyškumo. Daugumoje tyrimų naudojamas vidutinio stiprumo 15,5 ir 3 s spaudimas. Normalus KPL ịvairiose amžiaus grupèse skirtingas - jaunų vyrų jis turètų būti ne ilgesnis, nei $2 \mathrm{~s}$, moteru $-2,9 \mathrm{~s}$, o senyvo amžiaus žmonių neturètų viršyti 4,5 sekundès [8]. Pailgèjęs KPL ( $>4,5 \mathrm{~s})$ ịvairios etiologijos šoko metu turi ryši su blogesne baigtimi [10-12].

2019 m. atliktame ANDROMEDA tyrime negauta patikimų mirštamumo nuo sepsinio šoko skirtumų, lyginant grupes, kuriose kraujotaką gerinantis gydymas pagrịstas KPL bei laktatų koncentracijos pokyčiais. Reikia paminèti, kad po 72 val. nuo įtraukimo ị tyrimą, organų nepakankamumo atvejų statistiškai reikšmingai mažiau buvo KPL grupeje. Šioje grupejje pacientams buvo paskirta reikšmingai mažiau infuzinių tirpalu per pirmąsias 8 gydymo valandas, o tai gali tureti reikšmés organų nepakankamumo patogenezei [9]. Yra duomenų, kad KPL galètų būti naudingas išvengiant perteklinés infuzoterapijos dar ir todèl, kad patikimai parodo potencialų paciento atsaką i skysčius esant šokui, pasyvaus kojų pakèlimo mėginio metu. Jei atliekant ši manevrą KPL sutrumpeja 27 proc. ar daugiau, tikètinas hemodinamikos atsakas ị skysčiu infuziją (jautrumas 87\%, specifiškumas 100\%) [12].

Paminėtina, kad KPL turi tam tikrų trūkumų - tai vertinimo kintamumas tarp skirtingų tyrèjų, skirtingų tyrimo epizodų bei priklausomybè nuo aplinkos temperatūros ir apšvietimo [13,14].

Odos margumas. Odos margumas - tai plintančios melsvos dèmès, pirmiausia atsirandančios kelių bei alkūnių srityje. Jos atsiranda dèl heterogeniškos smulkiujų kraujagyslių vazokonstrikcijos ir manoma, jog atspindi sutrikusią odos perfuziją [1]. Tai vienas iš lengvai nustatomų klinikinių šoko požymių, turintis ryšị su mirštamumu [15]. Siekiant objektyvizuoti odos margumo vertinimą, buvo sukurta skalè, paremta margo ploto, besitęsiančio nuo kelio centro link periferijos, dydžiu. Šios skalès pagalba odos margumas ịvertinamas balais nuo 0 iki 5: 0 - margumo nèra; 1 - mažas (monetos dydžio) margas plotelis kelio centre; 2 - margumas 
neišplitęs už viršutinès girnelès ribos; 3 - margumas išplitęs ne toliau kaip iki šlaunies vidurio; 4 - margumas išplitęs iki kirkšnies raukšlès; 5 - margumas išplitęs už kirkšnies raukšlès (1 pav.) [16]. Kuo didesnis šis balas, tuo didesnis pacientų, kuriems yra šokas, mirštamumas [17]. Atlikta tyrimų, kurių metu bandyta odos margumą kelio srityje vertinti infraraudonujų spindulių termografijos būdu, tačiau gauti rezultatai neparodè šio metodo pranašumo, lyginant su standartine odos margumo skale [15].

Biocheminių audinių perfuzijos rodiklių vertinimas

Laktatų koncentracija. Tai bene plačiausiai naudojamas netiesioginis audinių kraujotakos rodiklis įvertinti gydymo efektyvumą audinių hipoperfuzijos atveju. R. Gotmaker ir kolegos nustate, kad kritinès būklès pacientų, kuriems patenkant ị gydymo įstaigą nustatyta padidejusi laktatų koncentracija, 90 dienų mirštamumas yra 1,7 karto didesnis, lyginant su tais, kuriems pasireiškè izoliuota refrakterinè hipotenzija be hiperlaktatemijos [18]. Laktatų koncentracija kraujyje $>2 \mathrm{mmol} / \mathrm{l}$ yra vienas iš sepsinio šoko nustatymo kriterijų. 2016 metais publikuotose sepsio gydymo gairèse rekomenduojama ịvertinti ši rodikli jau per pirmają sepsio ar sepsinio šoko gydymo valandą. Jei pirmojo matavimo metu nustatyta padidejusi laktatų koncentracija, ji turètų būti ivertinta pakartotinai per 2-4 val., skiriant optimalų gydymą, gerinantį audinių kraujotaką [19,20].

Yra mažiausiai keturi mechanizmai, dèl kurių gali didèti laktatų koncentracija kraujyje: 1) anaerobinè glikolizè zonose, kuriose audinių perfuzija nepakankama, ypač, kai yra sunkūs mikrocirkuliacijos sutrikimai; 2) pagreitèjusi aerobinè glikolizè dèl perteklinès beta adrenerginès stimuliacijos; 3 ) sumažejęs hepatinis laktatų klirensas ir 4) mitochondrijų disfunkcija, dèl kurios sutrinka piruvato metabolizmas [21].

Laktatacidozè skirstoma ị du tipus: A ir B. A tipas - audinių hipoperfuzijos sukelta laktatacidoze, kurios priežastys galètų būti kraujotakos nepakankamumas, širdies sustojimas, sunki hipoksemija, sunki anemija, regioninè audinių hipoperfuzija, traukuliai, anaerobinis fizinis krūvis. B tipo laktatacidozès metu laktato koncentracija didèja, nesant hipoksijos ląstelès lygmenyje. Ją gali sukelti tam tikri medikamentai (metforminas, acetaminofenas, simpatomimetikai ir kt.) ar

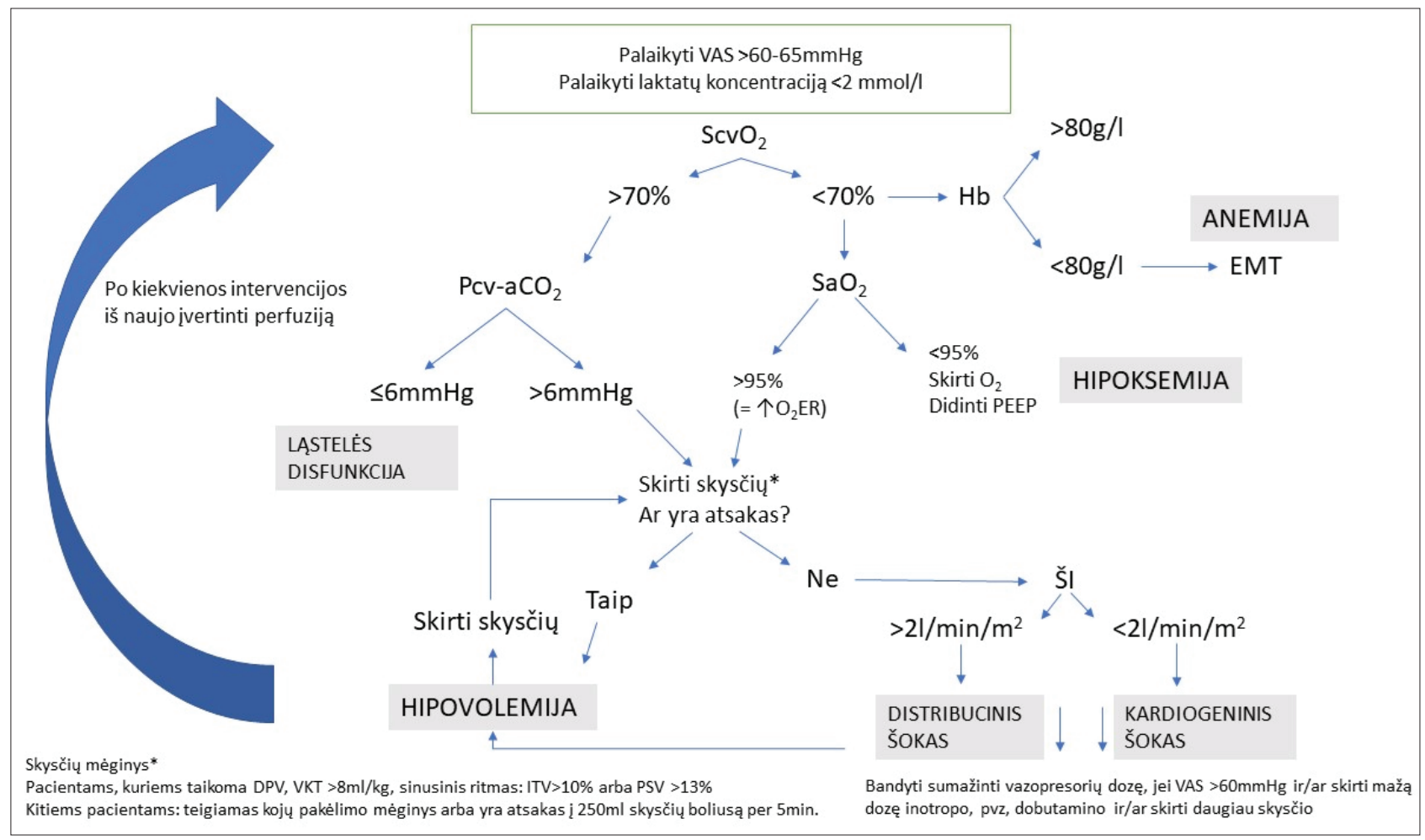

2 pav. $\mathrm{ScvO}_{2}$ ir $\mathrm{Pcv}-\mathrm{aCO}_{2}$ vertinimo seka šoko metu

$V A S$ - vidurinis arterinis kraujospüdis, $\mathrm{ScvO}_{2}$ centrinès venos kraujo isotinimas deguonimi, Hb - hemoglobinas, EMT - eritrocitu masès transfuzija, PEEP (angl. positive end expiratory pressure) - teigiamas slègis iškvépimo pabaigoje, $\mathrm{SaO}_{2}$ - arterinio kraujo įsotinimas deguonimi, $\mathrm{Pcv}_{-} \mathrm{CCO}_{2}$ - parcialinio anglies dioksido slègio skirtumas tarp arterinio bei centrinés venos kraujo, ŠI-širdies indeksas, DPV-dirbtiné plaučiu ventiliacija, VKT-vienkartinis kvépavimo tūris, STV-smüginio tūrio variabilumas, PSV-pulsinio spaudimo variabilumas.

Šaltinis: adaptuota pagal B. Vallet ir kolegas [35]. 
gretutinès ligos (kepenų patologija, inkstų nepakankamumas, tiamino stoka, onkologinès ligos, diabetinè ar alkoholinè ketoacidoze, igimtos mitochondriopatijos ir kt.) [22]. Nustatyta, kad tiek momentinis laktatų koncentracijos padidejimas, tiek jos mažejimas per pirmąsias 6 gydymo valandas turi ryšį su mirštamumu [23]. Svarbu atpažinti hiperlaktatemiją, kuri atsirado dèl hipoperfuzijos, nes audinių kraujotakos optimizavimas šiuo atveju gali pagerinti prognozę. Jei padidejusios laktatų koncentracijos priežastis kita, pernelyg atkaklus gydymas, siekiant ją normalizuoti, gali sukelti rimtų šalutinių reiškinių [21].

Esant normaliai laktatų koncentracijai serume, rezultatas iš veninio ir arterinio kraujo nesiskiria, tačiau esant hiperlaktatemijai, yra tam tikrų neatitikimų. Koncentracija iš centrinès venos bei arterijos paprastai sutampa ir parodo bendrą cirkuliuojančių kraujo laktatų koncentraciją. Iš periferinès venos kraujo nustatyta laktatų koncentracija labiau atspindi vietinę audinių kraujotaką. Jei nèra galimybės ištirti arterinį ar centrinès venos kraują, rekomenduojama tirti laktatų koncentraciją iš periferinès venos [22,24].

Natūraliai kyla klausimas, ar infuzoterapijai naudojamas Ringerio laktato tirpalas galètų turèti reikšmès laktato koncentracijos serume pokyčiams. Nustatyta, kad per vieną valandą sulašinus ị veną 1 litrą Ringerio laktato tirpalo, serumo koncentracija reikšmingai nesikeičia [25]. Vis dèlto inkstų transplantacijos metu Ringerio laktato grupejje pacientams skiriant infuziją $20-30 \mathrm{ml} / \mathrm{kg} / \mathrm{val}$ buvo nustatyta didesnè serumo laktato koncentracija, lyginant su $\mathrm{NaCl} 0,9$ proc. ar Plasmalyte tirpalu [26]. Tokie pat rezultatai buvo gauti gyviems kepenų donorams atliekant dešinę hepatektomiją, tačiau šis laktato koncentracijos padidejjimas buvo laikinas ir neturèjo ịtakos sergamumui ar mirštamumui [27].

Nustačius padidèjusią laktato koncentraciją, siūloma kartu ịvertinti dar tris nuo tèkmės priklausomus parametrus: mišraus veninio $\left(\mathrm{SvO}_{2}\right)$ ir centrinès venos kraujo ịsotinimą deguonimi $\left(\mathrm{ScvO}_{2}\right)$, centrinès venos ir arterinio kraujo $\mathrm{CO}_{2}$ gradientą $\left(\mathrm{Pcv}-\mathrm{aCO}_{2}\right)$ bei periferinę perfuziją (KPL, odos margumą, periferinès perfuzijos indeksą (PPI), odos temperatūrą). Pacientams, kurių laktatų koncentracija padidèjusi, sumažejęs $\mathrm{ScvO}_{2}$ arba padidejęs $\mathrm{Pcv}-\mathrm{aCO}_{2}$ arba pailgèjęs KPL, būdingas sunkesnio laipsnio kraujotakos nepakankamumas, lyginant su tais, kurių šie rodikliai nepakitę $[21,28]$. Išliekanti hiperlaktatemija be kitų audinių hipoperfuzijos požymių turi geresnę prognostinę reikšmę [28].

Mišraus veninio ir centrinès venos kraujo ịsotinimas deguonimi. Nors dèl kraujotakos heterogeniškumo ir sutrikusio audinių deguonies suvartojimo $\mathrm{SvO}_{2}$ išlieka aukštas, jo sumažejimas turi diagnostinę ir prognostinę vertę, nes išliekanti audinių hipoksija veikia uždegimo mediatorių sintezę, mitochondrijų funkciją, deguonies utilizavimo procesą bei didina mirštamumą $[29,30]$. Normos atveju šis rodiklis turètų siekti 70-75 procentus [1]. Kad galètume ji ịvertinti, reikia kateterizuoti plaučių arteriją. Mažiau invaziškas rodiklio atitikmuo - centrinès venos (CV) kraujo įsotinimas deguonimi. Nors rezultatai šiek tiek skiriasi ir kraujas iš $\mathrm{CV}$ neatspindi deguonies suvartojimo apatinėje kūno dalyje bei vidaus organuose, yra nuomonių, kad naudoti $\mathrm{ScvO}_{2}$ klinikinèje praktikoje priimtina [1]. Kritinès būklès pacientų, kuriems nustatytas kraujotakos nepakankamumas, $\mathrm{ScvO}_{2}$ (kai CV kateterio galas yra viršutinejje tuščiojoje venoje) randamas $7 \pm 4$ proc. didesnis, nei $\mathrm{SvO}_{2}$ [31]. Yra tyrimų, kurių rezultatai parodè, $\mathrm{kad} \mathrm{ScvO}_{2}$ patikimai neatspindi $\mathrm{SvO}_{2}$ pacientams, kuriems yra sepsis [32]. Normali $\mathrm{ScvO}_{2}$ verte் neekskliuduoja audinių hipoperfuzijos [33].

Centrinès venos ir arterinio kraujo $\mathrm{CO}_{2}$ gradientas. Panašiai kaip ir $\mathrm{ScvO}_{2}$, venoarterinis $\mathrm{CO}_{2}$ gradientas padeda netiesiogiai ịvertinti minutinị širdies tūrị ir gydymo adekvatumą. Jei deguonies pasisavinimas yra sutrikęs dèl netolygios mikrocirkuliacijos, $\mathrm{ScvO}_{2}$ gali būti normalus, nepaisant sumažèjusio minutinio širdies tūrio (MŠT). Tokiu atveju Pcv-aCO $>6$ mmHg nurodo, jog perfuzija nepakankama, nors $\mathrm{ScvO}_{2}>70$ procentu [34]. $\mathrm{CO}_{2}$ yra apie 20 kartų tirpesnis, negu deguonis, todèl didelè tikimybè, kad jis difunduos iš išeminių audinių į veninę kraujotaką. Dẻl to Pcv-aCO 2 yra jautrus audinių hipoperfuzijos žymuo [35]. Pacientų, kuriems šis rodiklis išlieka $>6 \mathrm{mmHg}$ ilgiau kaip 24 val., mirštamumas didesnis [33].

B. Vallet ir kolegos pasiūlè šoko diferencinès diagnostikos bei veiksmų algoritmą, pagrịstą $\mathrm{ScvO}_{2}$ ir Pcv-aCO vertinimu (2 pav.) [35]. Siektinas tikslas $\mathrm{ScvO}_{2}>70$ proc. ir Pcv-aCO $2<6 \mathrm{mmHg}$, tačiau nustačius tokias vertes, reikètų įsitikinti, jog nėra ląstelès disfunkcijos.

\section{Instrumentinis audinių perfuzijos vertinimas}

Periferinès perfuzijos indeksas. Periferinès perfuzijos indeksas apskaičiuojamas analizuojant pletizmografinę kreivę, gaunamą neinvazinès pulsoksimetrijos būdu [1]. Pulsoksimetrija pagrịsta tuo, kad per kapiliarų ložę (pirštas, ausies spenelis) sklinda dviejų skirtingų bangos ilgių šviesa (660 nm-raudona šviesa ir $940 \mathrm{~nm}$ - infraraudona šviesa). Hemoglobinas geriau absorbuoja $660 \mathrm{~nm}$ bangos ilgio šviesą, tuo tarpu oksihemoglobinas - $940 \mathrm{~nm}$ bangos ilgio šviesą. Deguonies įsotinimą daviklis apskaičiuoja kaip santykị tarp absorbuotos raudonos ir infraraudonos šviesos. Kaulai, jungiamasis audinys, veninis kraujas taip pat sugeria šviesą. Pulsoksimetro daviklis atskiria pulsuojantị (arterinè kraujotaka) ir nepulsuojantị (kiti audiniai) kraujotakos komponentus. Pulsuojantis komponentas panaudojamas apskaičiuojant arterinio kraujo įsotinimą deguonimi, tuo tarpu santykis tarp pulsinès ir nepulsinès kraujo tékmès 
periferiniuose audiniuose vadinamas periferinès perfuzijos indeksu, nepriklausančiu nuo paciento arterinio kraujo ịsotinimo deguonimi. Kai audinių kraujotaka sutrikusi, keičiasi pulsinis komponentas, o nepulsinis išlieka toks pat, todèl pasikeitęs santykis tarp jų atspindi periferinès perfuzijos pokyčius [8]. Dèl vazokonstrikcijos indeksas mažeja, o dèl vazodilatacijos - didejja [36]. Sveikų savanorių nustatyta PPI mediana 1,4, o kritinès būklès pacientų $<1,4$ PPI rodmuo parodo pablogèjusią periferinę perfuziją [37]. PPI išliekantis $<0,2$, nepaisant gydymo, turi tokio pat tikslumo prognostinę mirštamumo reikšmę, kaip laktatų koncentracija ir jos kitimas [38].

Tamsaus lauko kraštinio srauto videomikroskopija. Klinikinejje praktikoje intravitalinè mikroskopija pradèta naudoti devintajame dešimtmetyje ir turèjo didelę reikšmę, gilinant žinias apie mikrocirkuliacijos pokyčius kritinių būklių metu. Ilgainiui tamsaus lauko kraštinio srauto videomikroskopija tapo auksiniu audinių kraujotakos vertinimo standartu. Principas pagrịstas tuo, jog priglaudus daviklị prie gleivinès, prietaiso skleidžiamą poliarizuotą žalią šviesą absorbuoja hemoglobinas, todèl eritrocitai matomi kapiliaruose juodų taškelių pavidalu, tačiau kraujagyslių sienelès nematomos $[1,30]$.

Nors techniškai panaudojant videomikroskopiją galima ištirti kraujotaką bet kurioje gleivinejje ar organų paviršiuje, mikrocirkuliacija šiuo metodu dažniausiai vertinama poliežuvio srityje ar akies junginèje [39]. Poliežuvio sritis labiausiai ištirta, lengvai pasiekiama ir pokyčiai joje turi ryšį su organų nepakankamumo progresavimu bei mirštamumu [40,41]. Vertinami parametrai: perfuzuojamų kraujagyslių proporcija, bendras kapiliarų tankis, kraujotakos heterogeniškumas ir mikrokraujagyslių tėkmès indeksas (MFI - angl. microvascular flow index). Pastarasis apibūdina kraujo tèkmès greiti mikrokraujagyslèse. MFI $<2,6$ ir tachikardija $>90 \mathrm{k} / \mathrm{min}$ yra nepriklausomas mirštamumo ligoninejje rizikos veiksnys $[1,40]$. Svarbu tai, kad tamsaus lauko kraštinio srauto videomikroskopijos būdu minèti pokyčiai gali būti nustatyti labai anksti, o prognostinę vertę turi didesnę, nei MŠT, arterinis kraujospūdis ar $\mathrm{SvO}_{2}$. Anksti pagerinus mikrocirkuliacijos parametrus, pacientų išgyvenamumas gereja, o organų nepakankamumo atvejų nustatoma mažiau [30].

Mikrocirkuliacijos gerinimo būdai. Kertiniai gydymo būdai, gerinantys audinių kraujotaką, yra infuzoterapija ir vazopresorių infuzija. İ veną skiriami skysčiai padidina tèkmès slègi (angl. driving pressure), mažina kraujo klampumą, gerina endotelio bei cirkuliuojančių ląstelių ryšius. Tokiu būdu padideja perfuzuojamų kapiliarų proporcija, sumažeja tèkmès netolygumas [42]. Nustatyta, kad infuzoterapija gerina mikrocirkuliaciją ankstyvojoje sepsio gydymo stadijoje (iki 24 val.), tačiau vèliau ( $>48$ val.) jos reikšmė mažèja net ir tada, kai dèl infuzijos padidèja MŠT [1,42].

Pasitarnauti atrenkant pacientus, kuriems reikalinga infuzoterapija, galètų MFI vertinimas. Nustatyta, kad toje grupejje pacientų, kuriu pradinis MFI buvo $<2,6$, skysčiai reikšmingai ši indeksą padidino ir pagerino klinikinius periferinès perfuzijos rodiklius [41].

H. Ait-Oufella ir kolegų atliktoje studijoje, kurioje buvo vertinamas odos margumas, infuzoterapija ir vazopresoriai sumažino odos margumo laipsni, o pacientų, kurių margumo indeksas per pirmąsias 6 gydymo valandas sumažejo, išgyvenamumas buvo geresnis [16].

Liberali infuzoterapijos taktika gali tureti letalu poveiki dèl padidejusio kapiliarų pralaidumo nulemtos audinių edemos, pagilindama mikrocirkuliacijos sutrikimus [42]. Hemoraginio šoko metu hemodiliucija blogina audinių oksigenaciją labiau, nei kraujo netekimas [43]. Perteklinès infuzoterapijos sukeltas spaudimas veninejje sistemoje taip pat gali būti mikrocirkuliacijos sutrikimų priežastis [44].

Šoko metu hipotenzijos ir hipoperfuzijos gydymui naudinga noradrenalino infuzija. Tikètina, kad taip yra dèl hipotenzijos korekcijos, išsaugant optimalų perfuzini organų spaudimą. Tiems pacientams, kurių mikrocirkuliacijos rodikliai artimi normai, noradrenalinas poliežuvio kraujotakos reikšmingai negerina. Tyrimai parodè, kad didinant vidurinị arterinị kraujospūdį $>75$ ar $85 \mathrm{mmHg}$, mikrocirkuliacija nebegerèja $[42,45]$.

Mikrocirkuliacijos vertinimas galètų pasitarnauti priimant sprendimą dèl eritrocitų masės transfuzijos poreikio. Yra duomenų, kad pacientams, kurių mikrocirkuliacijos sutrikimai sunkūs ir yra anemija, eritrocitų masès transfuzija turi teigiamą efektą. Kai mikrocirkuliacija normali, eritrocitu masės transfuzija gali ją net pabloginti [46].

Buvo tirtas ir vazodilatatoriu poveikis mikrocirkuliacijai kritinių būklių metu. Pacientams, kuriems yra sunkus širdies nepakankamumas arba kardiogeninis šokas, skiriant nitrogliceriną ị veną, priklausomai nuo dozès, stebètas periferinès ir centrinès temperatūros gradiento sumažejjimas bei perfuzuojamų kapiliarų tankio padidejimas poliežuvio srityje [47]. Pacientams, kuriems yra sepsinis šokas, dvigubai aklo randomizuoto placebo kontroliuojamo tyrimo metu reikšmingo mikrocirkuliacijos pagerèjimo nenustatyta [48]. Tirtas ir magnio sulfato poveikis mikrocirkuliacijai sepsinio šoko metu, tačiau reikšmingų pokyčių negauta [49].

Prieštaringi duomenys ir apie dobutamino poveiki mikrocirkuliacijai. Tyrimai rodo, kad šio vaisto infuzija $5 \mu \mathrm{g} /$ $\mathrm{kg} / \mathrm{min}$ greičiu gali pagerinti audinių perfuziją ankstyvuoju sepsio periodu, tačiau visų kapiliarų nemobilizuoja [50]. G. Hernandez ir kolegų atliktame dvigubai aklame randomizuotame tyrime negauta patikimų mikrocirkuliacijos skirtumų tarp grupių, skiriant dobutaminą ir jo neskiriant [51]. 
Tyrimuose su graužikais nustatytas teigiamas askorbo rūgšties poveikis mikrocirkuliacijai ankstyvuoju sepsio periodu. $200 \mathrm{mg} / \mathrm{kg}$ dozė prieš sukeliant eksperimentinị sepsį, žiurkèms padejjo išvengti patologinès arteriolių konstrikcijos, gerino atsaką ị katecholaminus bei 24 valandų išgyvenamumą [52]. Tyrimų su kritinès būklès pacientais, kuriuose būtų nustatytas askorbo rūgšties poveikis mikrocirkuliacijai, trūksta.

\section{Išvados}

Neadekvati kraujotaka mikrokraujagyslèmis ypač svarbi organų nepakankamumo vystymuisi šoko metu. Nustatytas reikšmingas ryšys tarp audinių perfuzijos sutrikimų sunkumo laipsnio ir mirštamumo. Ankstyvas kraujotakos nepakankamumo nustatymas ir laiku atliktos terapinès intervencijos, gerinančios audinių perfuziją, didina pacientų išgyvenamumą.

\section{Literatūra}

1. Vincent J. Annual update in intensive care and emergency medicine 2020. Switzerland AG: Springer Nature 2020.

https://doi.org/10.1007/978-3-030-37323-8

2. Spanos A, Jhanji S, Vivian-Smith A, Harris T, Pearse RM. Early microvascular changes in sepsis and severe sepsis. Shock 2010;33(4):387-391.

https://doi.org/10.1097/SHK.0b013e3181c6be04

3. Jhanji S, Lee C, Watson D, Hinds C, Pearse RM. Microvascular flow and tissue oxygenation after major abdominal surgery: association with post-operative complications. Intensive Care Med 2009;35(4):671-677. https://doi.org/10.1007/s00134-008-1325-z

4. Kerger H, Waschke KF, Ackern KV, Tsai AG, Intaglietta M. Systemic and microcirculatory effects of autologous whole blood resuscitation in severe hemorrhagic shock. Am J Physiol 1999;276(6):H2035-43.

https://doi.org/10.1152/ajpheart.1999.276.6.H2035

5. De Backer D, Orbegozo Cortes D, Donadello K, Vincent JL. Pathophysiology of microcirculatory dysfunction and the pathogenesis of septic shock. Virulence 2014;5(1):73-79. https://doi.org/10.4161/viru.26482

6. Ince $\mathrm{C}$. Hemodynamic coherence and the rationale for monitoring the microcirculation. Crit Care 2015;19 Suppl 3(Suppl 3):S8. https://doi.org/10.1186/cc14726

7. Lima A, Jansen TC, van Bommel J, Ince C, Bakker J. The prognostic value of the subjective assessment of peripheral perfusion in critically ill patients. Crit Care Med 2009;37(3):934-938. https://doi.org/10.1097/CCM.0b013e31819869db

8. Lima A, Bakker J. Noninvasive monitoring of peripheral perfusion. Intensive Care Med 2005;31(10):1316-1326.

https://doi.org/10.1007/s00134-005-2790-2

9. Hernández G, Ospina-Tascón GA, Damiani LP, Estenssoro E,
Dubin A, Hurtado J, et al. Effect of a resuscitation strategy targeting peripheral perfusion status vs serum lactate levels on 28-day mortality among patients with septic shock: the ANDROMEDA-SHOCK randomized clinical trial. JAMA 2019;321(7):654-664.

https://doi.org/10.1001/jama.2019.0071

10. Schriger DL, Baraff L. Defining normal capillary refill: variation with age, sex, and temperature. Ann Emerg Med 1988;17(9):932-935.

https://doi.org/10.1016/S0196-0644(88)80675-9

11. Ait-Oufella H, Bige N, Boelle PY, Pichereau C, Alves M, Bertinchamp R, et al. Capillary refill time exploration during septic shock. Intensive Care Med 2014;40(7):958-964.

https://doi.org/10.1007/s00134-014-3326-4

12. Jacquet- Lagrèze $M$, Bouhamri N, Portran $P$, Schweizer R, Baudin F, Lilot M, et al. Capillary refill time variation induced by passive leg raising predicts capillary refill time response to volume expansion. Crit Care 2019;23(1):281-019-2560-0. https://doi.org/10.1186/s13054-019-2560-0

13. Sheridan DC, Baker SD, Kayser SA, Jones D, Hansen ML. Variability of capillary refill time among physician measurements. J Emerg Med 2017;53(5):e51-e57.

https://doi.org/10.1016/j.jemermed.2017.06.035

14. Shinozaki K, Capilupi MJ, Saeki K, Hirahara H, Horie K, Kobayashi N, et al. Low temperature increases capillary blood refill time following mechanical fingertip compression of healthy volunteers: prospective cohort study. J Clin Monit Comput 2019;33(2):259-267. https://doi.org/10.1007/s10877-018-0159-7

15. Ferraris A, Bouisse C, Mottard N, Thiollière F, Anselin S, Piriou V, et al. Mottling score and skin temperature in septic shock: relation and impact on prognosis in ICU. PLoS One 2018;13(8):e0202329.

https://doi.org/10.1371/journal.pone.0202329

16. Ait-Oufella H, Lemoinne S, Boelle PY, Galbois A, Baudel JL, Lemant J, et al. Mottling score predicts survival in septic shock. Intensive Care Med 2011;37(5):801-807.

https://doi.org/10.1007/s00134-011-2163-y

17. Coudroy R, Jamet A, Frat JP, Veinstein A, Chatellier D, Goudet $\mathrm{V}$, et al. Incidence and impact of skin mottling over the knee and its duration on outcome in critically ill patients. Intensive Care Med 2015;41(3):452-459. https://doi.org/10.1007/s00134-014-3600-5

18. Gotmaker R, Peake SL, Forbes A, Bellomo R, ARISE Investigators. Mortality is greater in septic patients with hyperlactatemia than with refractory hypotension. Shock 2017;48(3):294-300. https://doi.org/10.1097/SHK.0000000000000861

19. Levy MM, Evans LE, Rhodes A. The surviving sepsis campaign bundle: 2018 update. Crit Care Med 2018;46(6):997-1000. https://doi.org/10.1097/CCM.0000000000003119

20. Singer M, Deutschman CS, Seymour CW, Shankar-Hari M, 
Annane D, Bauer M, et al. The third international consensus definitions for sepsis and septic shock (Sepsis-3). JAMA 2016;315(8):801-810.

https://doi.org/10.1001/jama.2016.0287

21. Hernandez G, Bellomo R, Bakker J. The ten pitfalls of lactate clearance in sepsis. Intensive Care Med 2019;45(1):82-85. https://doi.org/10.1007/s00134-018-5213-x

22. Wardi G, Brice J, Correia M, Liu D, Self M, Tainter C. Demystifying lactate in the emergency department. Ann Emerg Med 2020;75(2):287-298.

https://doi.org/10.1016/j.annemergmed.2019.06.027

23. Ryoo SM, Lee J, Lee YS, Lee JH, Lim KS, Huh JW, et al. Lactate level versus lactate clearance for predicting mortality in patients with septic shock defined by sepsis-3. Crit Care Med 2018;46(6):e489-e495.

https://doi.org/10.1097/CCM.0000000000003030

24. Theerawit P, Na Petvicharn C, Tangsujaritvijit V, Sutherasan Y. The correlation between ar-terial lactate and venous lactate in patients with sepsis and septic shock. J Intensive Care Med 2018;33(2):116-120.

https://doi.org/10.1177/0885066616663169

25. Didwania A, Miller J, Kassel D, Jackson Jr EV, Chernow B. Effect of intravenous lactated Ringer's solution infusion on the circulating lactate concentration: part 3. Results of a prospective, randomized, double-blind, placebo-controlled trial. Crit Care Med 1997;25(11):1851-1854. https://doi.org/10.1097/00003246-199711000-00024

26. Hadimioglu N, Saadawy I, Saglam T, Ertug Z, Dinckan A. The effect of different crystalloid solutions on acid-base balance and early kidney function after kidney transplantation. Anesth Analg 2008;107(1):264-269.

https://doi.org/10.1213/ane.0b013e3181732d64

27. Shin WJ, Kim YK, Bang JY, Cho SK, Han SM, Hwang GS. Lactate and liver function tests after living donor right hepatectomy: a comparison of solutions with and without lactate. Acta Anaesthesiol Scand 2011;55(5):558-564.

https://doi.org/10.1111/j.1399-6576.2011.02398.x

28. Alegria L, Vera M, Dreyse J, Castro R, Carpio D, Henriquez $\mathrm{C}$, et al. A hypoperfusion context may aid to interpret hyperlactatemia in sepsis-3 septic shock patients: a proof-of-concept study. Ann Intensive Care 2017;7(1):29-017-0253-x. https://doi.org/10.1186/s13613-017-0253-x

29. Rivers E. Mixed vs central venous oxygen saturation may be not numerically equal, but both are still clinically useful. Chest 2006;129(3):507-508.

https://doi.org/10.1378/chest.129.3.507

30. De Backer D, Ospina-Tascon G, Salgado D, Favory R, Creteur $\mathrm{J}$, Vincent JL. Monitoring the microcirculation in the critically ill patient: current methods and future approaches. Intensive Care Med 2010;36(11):1813-1825.

https://doi.org/10.1007/s00134-010-2005-3
31. Reinhart K, Kuhn HJ, Hartog C, Bredle DL. Continuous central venous and pulmonary artery oxygen saturation monitoring in the critically ill. Intensive Care Med 2004;30(8):1572-1578. https://doi.org/10.1007/s00134-004-2337-y

32. van Beest PA, van Ingen J, Boerma EC, Holman ND, Groen H, Koopmans M, et al. No agreement of mixed venous and central venous saturation in sepsis, independent of sepsis origin. Crit Care 2010;14(6):R219.

https://doi.org/10.1186/cc9348

33. van Beest PA, Lont MC, Holman ND, Loef B, Kuiper MA, Boerma EC. Central venous-arterial $\mathrm{pCO}_{2}$ difference as a tool in resuscitation of septic patients. Intensive Care Med 2013;39(6):1034-1039.

https://doi.org/10.1007/s00134-013-2888-x

34. Huber W, Zanner R, Schneider G, Schmid R, Lahmer T. Assessment of regional perfusion and organ function: less and non-invasive techniques. Front Med (Lausanne) 2019;6:50. https://doi.org/10.3389/fmed.2019.00050

35. Vallet B, Pinsky MR, Cecconi M. Resuscitation of patients with septic shock: please "mind the gap"! Intensive Care Med 2013;39(9):1653-1655.

https://doi.org/10.1007/s00134-013-2998-5

36. Hales JR, Stephens FR, Fawcett AA, Daniel K, Sheahan J, Westerman RA, et al. Observations on a new non-invasive monitor of skin blood flow. Clin Exp Pharmacol Physiol 1989;16(5):403-415. https://doi.org/10.1111/j.1440-1681.1989.tb01578.x

37. Lima AP, Beelen P, Bakker J. Use of a peripheral perfusion index derived from the pulse oximetry signal as a noninvasive indicator of perfusion. Crit Care Med 2002;30(6):1210-1213. https://doi.org/10.1097/00003246-200206000-00006

38. He HW, Liu DW, Long Y, Wang XT. The peripheral perfusion index and transcutaneous oxygen challenge test are predictive of mortality in septic patients after resuscitation. Crit Care 2013;17(3):R116. https://doi.org/10.1186/cc12788

39. Simkiene J, Pranskuniene Z, Vitkauskiene A, Pilvinis V, Boerma EC, Pranskunas A. Ocular microvascular changes in patients with sepsis: a prospective observational study. Ann Intensive Care 2020;10(1):38-020-00655-x. https://doi.org/10.1186/s13613-020-00655-x

40. Ince C, Boerma EC, Cecconi M, De Backer D, Shapiro NI, Duranteau J, et al. Second consensus on the assessment of sublingual microcirculation in critically ill patients: results from a task force of the European Society of intensive care medicine. Intensive Care Med 2018;44(3):281-299. https://doi.org/10.1007/s00134-018-5070-7

41. Pranskunas A, Koopmans M, Koetsier PM, Pilvinis V, Boerma EC. Microcirculatory blood flow as a tool to select ICU patients eligible for fluid therapy. Intensive Care Med 2013;39(4):612-619. 
https://doi.org/10.1007/s00134-012-2793-8

42. De Backer D, Donadello K, Taccone FS, Ospina-Tascon G, Salgado D, Vincent JL. Microcirculatory alterations: potential mechanisms and implications for therapy. Ann Intensive Care 2011;1(1):27-5820-1-27.

https://doi.org/10.1186/2110-5820-1-27

43. Dilken O, Ergin B, Ince C. Assessment of sublingual microcirculation in critically ill patients: consensus and debate. Ann Transl Med 2020;8(12):793.

https://doi.org/10.21037/atm.2020.03.222

44. Vellinga NA, Ince C, Boerma EC. Elevated central venous pressure is associated with impairment of microcirculatory blood flow in sepsis: a hypothesis generating post hoc analysis. BMC Anesthesiol 2013;13:17-2253-13-17.

https://doi.org/10.1186/1471-2253-13-17

45. Tafner PFDA, Chen FK, Rabello RF, CorrÃ $\tilde{A}^{\mathrm{a} a}$ TD, Chaves RCF, Serpa AN. Recent advances in bedside microcirculation assessment in critically ill patients. Rev Bras Ter Intensiva 2017;29(2):238-247.

https://doi.org/10.5935/0103-507X.20170033

46. Nielsen ND, Martin-Loeches I, Wentowski C. The effects of red blood cell transfusion on tissue oxygenation and the microcirculation in the intensive care unit: a systematic review. Transfus Med Rev 2017;31(4):205-222.

https://doi.org/10.1016/j.tmrv.2017.07.003

47. den Uil CA, Caliskan K, Lagrand WK, van der Ent M, Jewbali LS, van Kuijk JP, et al. Dose-dependent benefit of nitroglycerin on microcirculation of patients with severe heart failure. Intensive Care Med 2009;35(11):1893-1899.

https://doi.org/10.1007/s00134-009-1591-4

48. Boerma EC, Koopmans M, Konijn A, Kaiferova K, Bakker AJ, van Roon EN, et al. Effects of nitroglycerin on sublingual microcirculatory blood flow in patients with severe sepsis/ septic shock after a strict resuscitation protocol: a doubleblind randomized placebo controlled trial. Crit Care Med 2010;38(1):93-100. https://doi.org/10.1097/CCM.0b013e3181b02fc1

49. Pranskunas A, Vellinga NA, Pilvinis V, Koopmans M, Boerma EC. Microcirculatory changes during open label magnesium sulphate infusion in patients with severe sepsis and septic shock. BMC Anesthesiol 2011;11:12-2253-11-12.

https://doi.org/10.1186/1471-2253-11-12
50. De Backer D, Creteur J, Dubois MJ, Sakr Y, Koch M, Verdant C, et al. The effects of dobutamine on microcirculatory alterations in patients with septic shock are independent of its systemic effects. Crit Care Med 2006;34(2):403-408. https://doi.org/10.1097/01.CCM.0000198107.61493.5A

51. Hernandez G, Bruhn A, Luengo C, Regueira T, Kattan E, Fuentealba A, et al. Effects of dobutamine on systemic, regional and microcirculatory perfusion parameters in septic shock: a randomized, placebo-controlled, double-blind, crossover study. Intensive Care Med 2013;39(8):1435-1443.

https://doi.org/10.1007/s00134-013-2982-0

52. Oudemans-van Straaten HM, Spoelstra-de Man AM, de Waard MC. Vitamin C revisited. Crit Care 2014;18(4):460014-0460-x.

https://doi.org/10.1186/s13054-014-0460-x

\section{ASSESSMENT OF TISSUE PERFUSION DURING SHOCK}

E. Belousovienė, E. Morkūnas, J. Šimkienė, I. Kiudulaitė, V. Pilvinis, A. Pranskūnas

Keywords: tissue perfusion, microcirculation, shock.

Summary

Inadequate tissue perfusion is a cornerstone of the development of multiple organ failure during shock. A degree of microcirculatory dysfunction has a clear relation to the higher mortality of critically ill patients. Therefore, it is vital to identify impairment of tissue perfusion and start therapy as early as possible. This article aims to review the recent literature describing non-invasive methods for the assessment and improvement of tissue perfusion. Data were collected in the Pubmed database using the keywords: tissue perfusion, microcirculation, shock. Fifty-two full-text articles in English were selected and analyzed. Based on the results of selected articles, we can state that the assessment of tissue perfusion using clinical, biochemical, and instrumental methods allows early detection of microcirculatory impairment. Early detection of microcirculatory failure, and timely therapeutic interventions that improve tissue perfusion, increase the survival of patients with shock.

Correspondence to: egle.belousoviene@1smuni.1t

Gauta 2020-07-24 